\title{
PARTICIPATION OF INDIVIDUALS IN PUBLIC DECISIONS IN THE POLISH LEGAL SYSTEM-THE OUTLINE

\author{
Agata Barczewska-Dziobek ${ }^{1}$
}

\begin{abstract}
The idea of good governance is associated with the postulate of participatory and interactive democracy. This results in the appearance in the legal system of solutions reflecting the recommendations of the so-called "good administration." Good administration is the subjective right which, in the relationship between the body and the citizen, defines the individual's rights and the duties of the administration to act in a particular way. It may be interpreted differently, but it must comply with universal standards. They have been defined in international, European and soft law. These include the rule of law, equality, administrative transparency, confidence and trust, as well as the opportunity to participate in decisions. The last of these relates to procedures for involving citizens in administrative decision-making.

The purpose of the article is to present normative solutions in Polish law that guarantee citizens participation in decisionmaking processes at various levels of administration and their systematics. To achieve this goal, the method of legal text analysis was used, which allows us to indicate the existence of many different mechanisms of participation. Their presence in Polish law determines the varying levels of civic influence on public decisions.
\end{abstract}

UDC Classification: 342.1, DOI: https://doi.org/10.12955/pss.v1.40

Keywords: good governance, right to good administration, participation, administrative decision-making

\section{Introduction:}

Participatory democracyhas its origins in ancient times. The model of democracy of ancient Athens assumed the direct participation of individuals in the power realized in their folk assemblies - known as ekklesia (Hansen, 1999, p.144-145). This became the benchmark for direct participation, a modern version of which we can observe in Switzerland. The model of model participatory democracy is undergoing transformation together with major nations and states, according to today's application in the use of these principles of semi-direct democracy (Uziębło, 2009, p.17-18). Various forms of participatory democracy in modern cases are a consequence of reform in the last few decades. They were inspired by the idea of good public management and good governance (Guy Peters, 2018), which are a response to the crisis of representative democracy. Starting with theoretical assumptions to increase citizen participation in public life, the idea of good administration has become a subjective right guaranteed by European Union law (Act No. 2012 / C 326/02, Call.). However, they only bind EU institutions, which does not mean that we do not find solutions in the national legal systems that are equivalent to this right, because every democracy implies by its nature some participation of citizens in power. Therefore, the question arises whether there are solutions in the Polish law system that relate to the participatory way of making public decisions in the spirit of the concept of good governance, what their nature is and whether they can be classified.

\section{Participation of individuals in public decisions in the Polish legal system}

Pursuant to the Constitution, the Republic of Poland is a democratic state ruled by law (Law No. 78/1997 Call.). It follows that the enacted law implements democratic standards related to the existence of guarantees of the legal influence of citizens on power. This influence takes various forms, each of which is regulated by a different piece of legislation.

The condition of influence on the authorities is access to information on its operation, which as a right to public information is guaranteed in the Constitution itself and in the Act of 2001 (Law No 1429/2019, call.). Constitutional Norms declare the principle of openness of the authorities' activities. According to them, a citizen has the right to obtain information about the activities of public authorities and persons performing public functions. The scope of this right includes obtaining information on the activities of economic and professional self-government bodies, as well as other persons and organizational units to the extent that they perform public authority tasks and manage municipal property or State Treasury property. The right to obtain information includes access to documents and admission to meetings of collegiate public authorities coming from general elections, with the option of recording audio or video. By exercising their right, citizens have the opportunity to obtain public information. It consists of the right to immediately obtain such information, which contains current knowledge about public matters. The right to public information consists of the rights to: obtain public information, inspect official

\footnotetext{
${ }^{1}$ University of Rzeszow, Faculty of Law, Department of Administrative Science, adziobek@ur.edu.pl
} 
documents, access to meetings of collegiate public authorities coming from universal suffrage. Everyone has this right. The person requesting public information may not be required to substantiate the request. The entity's entitlement is connected with the publication obligation on the part of the authorities. Each authority entity (including public administration) must publish a set of information about the legal bases of its operation, its structure, persons holding positions, tasks performed and public funds. This information is published on websites in an electronic newsletter.

Further expression of the influence of individuals on the authorities is the individual's right to fill the authorities through elections within the system of representative democracy and the right to influence the content of the authority's decision by participating in a referendum.

Filling public positions in public administration is regulated by the norms of law shaping the structure of public authorities coming from direct elections. With reference to the structures of the Polish public administration, here we will refer to local government bodies in communes (Law. No 713/2020, Call.), Poviats (Law. No 511/2019, Call.) and local government (Law, No 512/2019, Call.): Voivodship parliament, poviat council, commune council as constitutive bodies as well as commune heads, mayors and presidents of cities - as executive bodies of communes. These bodies have a term of office and are filled by candidates selected by way of elections.

The second of the above-mentioned forms is reflected in the laws on the nationwide referendum (Law No 1444/2019, Call.) and local (Law No 84/1996, Call.). These provisions allow citizens to vote widely, and thus to participate in public life. According to them, in a referendum, residents as members of the community express their will on how to deal with any important matter of this community, of a social or economic nature. They can shape decisions in local matters, e.g. dismissal of an executive body in a commune, designation of land for investment, and indication of a selective waste collection point; matters of regional scope, such as privatization of an enterprise, construction of a waste incineration plant, or nationwide.

The referendums provided for in the regulations are divided into obligatory and optional, which is directly related to the nature of the case and the rank assigned to it by the legislator. An obligatory referendum provides for the provisions of the Act on the local referendum. These are referendums on the following matters: dismissal of the commune head (mayor, city president) and self-taxation of residents for public purposes within the scope of tasks and competences of the commune authorities. In these cases, the referendum is managed on the basis of a resolution of the decision-making body. Optional referendums are initiated by a group of authorized persons specified in the regulations - the threshold is $10 \%$ of those authorized in the case of a local referendum and 500,000 citizens in the case of a nationwide one.

The local referendum has a binding dimension for the authorities, if the conditions specified in the law are met, i.e. when at least half of the eligible citizens took part in it - for the national and 3/5 for the local ( $2 / 3$ in cases of self-taxation). A nationwide referendum is valid and binding when more than half of those entitled to vote took part. The turnout threshold in a national referendum means it does not affect its validity, but determines its opinion-making or binding nature.

Among the legal instruments guaranteeing individuals participation in decisions taken by the authorities, the right of petition can also be mentioned. The right of petition is guaranteed in the Polish Constitution of 1997, but until 2014 it did not have a detailed development in the Act. (Law No 870/2018, Call.), Which to some extent embodies the right of citizen participation in power, as it grants them the opportunity to make a constructive application in the matter of public administration. The subject of a petition may be a request to change the law, to make a decision or act for the petitioner, for collective life or value in the name of the common good. Submission of a petition raises the obligation to respond to its content, although it does not result in the obligation to take it into account.

Participation of citizens in power is implemented in the legal forms of semi-indirect democracy (Uziębło, 2006, p. 61). These include instruments in which a collective sovereign, group or entity participates in the decision-making process (public decision), except that the final content of the decision depends on the authority. Public decisions should include decisions on intentions and behavior of the administration in collective matters, except that its legal form is irrelevant. It can take the form of a normative act, either a public policy or specific action for the collective (Rainey et al., 2010, p.349). 
In this category you can find a number of regulations related to consultation processes. The concept of (social) consultations is a collective definition of processes in which representatives of public authorities present to citizens, their groups, non-governmental organizations their intentions regarding e.g. normative acts and other activities that will affect the everyday life of a given community. The public consultation process includes presenting information on intentions, listening to opinions, modifying planned intentions and making decisions by the authorities.

Considering the level of public administration, the legal basis for public consultations can be found in the regulations on the operation of government administration bodies - the Council of Ministers (Law No 1171/2019, Call.). They provide for internal expert consultations on draft normative acts and other documents, e.g. programs. Citizens' participation in their development is carried out at the stage of developing the impact assessment of planned legal regulations, which, according to the regulations of the Council of Ministers, must contain a description of the economic and social effects and information on obligatory consultations. Opinions collected at this stage are not binding on the authority.

Another example of a law presupposing consultations at the central level are provisions on the principles of conducting development policy (Law No 1295/2019, call.). These provisions directly implement EU standards for shaping public policies imposing obligations on Member States to use consultation procedures (UE Commision, 2015).

Public policies (politics, policy) have a long history (W.N. Dunn, 1981), although they still do not have a clear definition. It can be assumed that these are processes related to achieving goals (Arral et al., 2012, p. 3-17), in which, apart from public actors, there are citizens as entities co-shaping the ways of achieving public goals and their addressees. In Polish law, public policies can be used to describe all plans, programs of a strategic and executive nature, general and domain developed at national, regional and local level. The preparation of their content must be preceded by public consultations, as a result of which the content of policies may undergo transformations as a result of taking public opinion into account. the provisions on shaping development policies do not include the obligation to take into account comments submitted during consultations, but impose two obligations on authorities: referring to each of the comments and opinions submitted and justifying their rejection, as well as disclosing the consultation process and their result by publishing the reports online (Law No 1295/2019, call.).

Public consultations at the local level are conducted on the basis of constitutional provisions: the Act on commune self-government (Law No 713/2020, call.), On poviat self-government (Law No 511/2019, call.) And on self-government voivodship (Law No. 512 / 2019, call.) Consultation with residents is provided for in each of these legal regulations. Pursuant to the provisions, obligatory consultations are carried out when: the boundaries of the entity's territory are to be changed, the territory is divided or merged, the name is changed and the seat of the authorities is changed. Other matters regarding the scope of activity of the local government community, considered important, may be subject to optional consultations. Bodies constituting local government units are obliged to take an act of local law in matters of consultation procedure in their area. Consultations are used to organize decision making in such a way as to enable the commune authorities to get acquainted with the opinions of third parties, but they do not create the law.

In addition to the examples of norms regulating consultations under the Polish law system, other examples can be found. These are mainly standards for public tasks, e.g. land use law (Law No 293/2020, call.) which imposes a consultative obligation regarding the draft land use plan, social assistance law (Law No 508/2018, call.) which provides for social consultations during the development of strategies for solving social problems and provisions for the revitalization of areas. In the category of legal solutions in the field of public tasks, there are also provisions on the operation of the selfgovernment province, because it operates on the basis of development strategies and policies. The adoption of these documents must be preceded by obligatory consultations: these are the voivodship development strategy, voivodship operational programs, voivodship sectoral programs (Law No 512/2019, call.).

A special example of the consultation procedure is the civic budget. Its creation is envisaged by the aforementioned constitutional provisions regarding Polish municipalities. As part of the civic budget, residents directly vote on a part of the municipality's budget expenditure each year. Tasks selected under the civic budget are included in the commune's budget resolution. In the course of work on the draft 
budget resolution, the commune council may not remove or significantly change the tasks selected under the civic budget. The regulations provide that in municipalities that are cities with poviat rights, the creation of a civic budget is obligatory. The detailed procedure for developing the civic budget is shaped on the basis of an act of local law, in which the requirements for those entitled to participate in these consultations, the manner of submitting tasks, criteria for assessing their legitimacy and criteria for selecting priority tasks can be defined in any manner.

A separate legal basis for participatory instruments, including a consultation mechanism, is also provided for by provisions on administrative cooperation with non-governmental organizations (Law No 688/2019, call.). These standards introduce the obligation of permanent cooperation between public administration bodies and non-governmental organizations, which concerns the performance of public tasks. The regulations provide for the following forms: commissioning tasks with subsidies, mutual information on planned activities in order to harmonize them, consulting draft normative acts, creating joint advisory and advisory teams. It provides for consultations on cooperation programs between local government units and non-governmental organizations, which must be implemented obligatorily. With regard to the participation of individuals in decision-making processes, e.g. about the shape of the program, the opinion-making and advisory teams and public benefit councils play a significant role. These councils are compulsorily created by law at the central level, while at the local level they have to be established - at the executive bodies of local self-government, if an authorized number of nongovernmental organizations requests their creation. The Act introduces the obligation to maintain parity in determining the composition of public benefit councils, at least half of the members must be representatives of non-governmental organizations operating on the territory of a given body. The basic tasks of public benefit councils as consultative and advisory bodies include expressing opinions: on draft resolutions and legal acts regarding the activities of non-governmental organizations, on public tasks commissioned to non-governmental organizations and their standards, as well as on the draft of strategic documents (voivodships, poviats, communes).

\section{Data and Methodology:}

The methodology which is used in this research is firmly rooted in the field of legal science. It is qualitative in nature. Critical-analytical, textual, teleological, logical and synthetic methods are used. The use of findings from other disciplines is limited to supporting the argumentation pertaining to the field of law.

The textual method is the first level of analyzing legal norms, which should be supplemented with other approaches only when the text is not sufficiently non-ambiguous to yield a satisfactory result (MacCormick, 1993, p.26-29). A teleological or purposive approach is used to supplement the textual method. Namely, since regulations are purposive in terms of trying to achieve policy aims, they should be read so, that their purpose is taken into account (Stack, 2012, p.361).

A Llogical method is used to form arguments and draw conclusions regarding different relevant aspects of the research topic. In this sense, especially informal logic is applied, since in legal logic, deduction is supplemented with informal approaches regarding information flow, argumentation and interaction (Prakken \& Sartor, 2015, p.214-245). A synthetic method is used in the final chapter in order to draw conclusions and synthesize the performed research. Interdisciplinary considerations are made only where relevant in order to support the main arguments. They are drawn especially from the fields of sociological studies and policy studies.

The research assumption undertaken in this study was to determine whether there are solutions in Polish law that guarantee individuals participation in decisions taken by authorities. Such a right as a subjective right is an emanation of the standard of good administration and is part of the EU concept of increasing the active participation of citizens in public life, which is in line with the idea of good governance.

In order to make the above, it was necessary to define the essence of the right to good administration, which in this case consists of the existence of participatory mechanisms. Participation must be understood here as a complex concept, which consists of a number of instruments enabling the individual to take part in the decision-making process created by the authority, and on the other hand the existence of at least an obligation of the authority to include the individual in his decision-making process. The decision-making process itself refers to the actions taken at the stage preceding the decision, which is its final result. The methodological difficulty on the basis of legal research results from a different 
understanding of the concept of decision in this area, which is why the study adopts categories of public decision, i.e. the result of the action of the authority whose essence is to decide on a public case of a collective nature. One example of such a decision is a normative act because it meets the criteria of universality of impact and is of a general nature. Programming decisions are the second example. They do not contain legal norms, but norms specifying goals. This is the nature of planning documents strategies, programs and action plans. In the Polish literature on the subject, the concept of public decision is an unknown concept and does not appear as a legal term. Therefore, it was necessary to substitute certain acts of power in this category.

The next stage of the study was to extract from all legal norms those that relate to the procedures for making these decisions, and then to indicate such procedural solutions in which the legislator envisages the participation of the individual in this process. Due to the framework of the study and the assumption about presenting some solutions, the separation was made using the criterion of the organizational level - central authorities and local authorities. An additional criterion enabling the identification of examples of solutions was the criterion of the nature of a legal act - an act of constitutional law and substantive law.

Supporting further analysis was the concept of participation, derived from the field of social sciences, used in the legal sciences for the creation of concepts and verification of standards.

\section{Results and Discussion:}

Decision making should be based on a model solution called rational decision-making, which presupposes that the public decision-maker is subject to various restrictions when making his decisions. One of them is imperfect information, which creates risk as to the proper determination of the goals and results of the decision. This affects the final enforceability of the decision, which can be measured by compliance with the addressee of its content. In view of the complexity of the decision-making phenomenon, the public decision-maker, striving for a certain degree of rationality, must move within the so-called limited rationality. One important limitation is the decision-maker's access to information, which consequently results in a lack of proper assessment of the goals and results to be achieved by means of a decision. (Simon, 1976, p. 61). Considering the decision as a non-random choice of a specific solution to a given social problem, it must be kept in mind that, first of all, its content must be consistent with current social demand to avoid situations where the content of the decision is divergent with social expectations. In this case, one can speak of generating by individuals decisively unreasonable the phenomenon of individual or social injustice (Hammond, 1996, p.33).

Due to this, it is important that the framework of decision-making in public administration provided for by legal norms provides for the possibility of including the addressee of the decision in the decisionmaking process, regardless of its final nature (https://extension.umn.edu/public-engagementstrategies/five-reasons-involve-others-public-decisions). This is a postulate consistent with the assumptions of the right to good administration. Good administration is one that implements human rights standards, and therefore there is a close relationship between human rights and good administration (Kucsko-Stadlmayer, 2008, p.37) The value of good administration is assessed through the prism of implementing its standards, which at the current regulatory stage take on the nature of legal principles. They are the rule of law, equality, administrative transparency, certainty and trust, as well as the principle of the participation of individuals in decisions.

These principles were initially expressed in the form of recommendations of the European Code of Good Administration, and then adopted as normative in the provisions of the European Charter of Fundamental Rights (Batalli and Fejuzullahu, 2018, p.27). As a result, guarantees arising from these principles of rights should be found in national normative systems.

The aim of the study was to verify the assumption that normative solutions exist in the Polish legal system that guarantee citizens participation in public decisions taken at various levels of administration.

As a result of the analysis of normative acts, the following findings were made:

- participation in power is conditioned by access to information from the authority and its activities - this is guaranteed in connection with the principle of openness of the authorities' operation and the right to public information,

- participation in power is regulated by norms of the constitution and ordinary laws - the presented selection of norms illustrates the existence of this right, 
- participation in power takes various legal forms - analysis of legal texts indicates the right to information, petitions, formation of personal compositions of bodies from general elections, the right to express opinions, the right to participate in collective advisory and advisory bodies, the right to decide on the way administrative bodies operate, the right to decide on the allocation of public funds,

- participation in power may have the form of influence on the content of decisions taken by the authority - the right to take a position as a form of influence of low intensity and the right to shape the content of the decision as a form of co-decision,

- impact on the content of the decision - civic budget - decision on the entity's website

It should be noted that the indicated instruments for shaping public decisions are heterogeneous and their legal foundations are found in many provisions.

However, it can be stated that the participation of individuals in public decisions is implemented at every level of public administration in Poland. The most impact instruments are contained in the provisions regarding the system and operation of local government units.

Based on the analysis of the legal text, it is difficult to determine the proportions between the number of instruments related to co-shaping normative acts and other acts of collective authority. Therefore, the above findings are initial for further empirical and comparative research. During their conduct, further research questions arose regarding the effectiveness of these instruments

\section{Conclusions:}

The idea of good governance (Bevir, 2010) is associated with the concept of good administration, which has now acquired legal status. This is the right to good administration, within which certain principles and standards are implemented. One of them is participation. Participation, meaning the participation of individuals in power, can take various forms. It can be implemented at the legislative or executive level, depending on the adopted regulatory model.

Participatory instruments can be graded:

1) the least involving units - providing information on planned activities - unilateral and non-interactive,

2) moderately involving involvement in decision-making processes - collecting opinions without the obligation to take them into account - bilateral and interactive (rejection of opinions must be justified),

3) co-decision - transfer of the right to shape the content of the final decision to individuals.

In Polish law, there are solutions that guarantee the participation of individuals in decisions taken by the public administration.

Public consultations as the basic form of participation are a way of obtaining the opinions of those who are to be affected by the effects of public decisions. They are based primarily on collecting positions and assessments of addressees of public decisions, but it is also possible to indicate such procedures, as a result of which the process of co-shaping public decisions takes place, or simply about determining their content (participatory budget).

As a rule, the law does not prejudge the form of consultation: that is why they can be shaped flexibly. Public consultations in local government may take the form of: written opinions of authorities, discussion meetings, arrangements, appointment of consultative boards, street surveys, or surveys.

\section{References:}

Bevir M. (ed.), (2010), The SAGE Handbook of governance, Berkeley, Sage Publication Ldt.

Democracy, retrieved from URL https://www.coe.int/en/web/compass/democracy,

Dunn W. N., (1981), Public Policy Analisys: An Introduction, Englewood Cliffs, N.J. : Prentice- Hall,

Araral E., Fritzen S., Howlett M., (2012), Routledge Handbook of Public Policy, London \& New York: Routlege,

Five Reasons to involve others in public decisions, retrieved from URL https://extension.umn.edu/public-engagementstrategies/five-reasons-involve-others-public-decisions

Hammond K.R., (1996), Human Judgment and Social Policy, Oxford University Press,

Hansen M. H., (1999), The Athenian Democracy in the Age of Demostenes: Sturcture, Principles, and Ideology, University of Oklahoma Press, Morgan,

Kucsko-Stadlmayer G. (ed.), (2008), European Ombudsman-Institutions Of Comparative Legal Analysis Regarding The Multifaceted Realization of An Idea, Wien, Springer, 
Natalli M., Fejuzullahu A., (2018), Principles of Good Administration Under The European Code of Good Administrative Behaviour, Pecs Journal of International and European Law, 1, pp. 26-35, retrieved from URL http://ceere.eu/pjiel/wpcontent/uploads/2018/08/28_pjielPJIEL1801.pdf.

Peters B.Guy, (2018), The Politics of Bureaucracy. An introduction to Comparative Public Administration, New York and London, Routlege,

Quality of Public Administration, A Toolbox for Practitioners, (2015), Retrieved from URL http://ec.europa.eu/esf/toolbox.

Rainey H.G., Ronquillo J.C., Avellaneda C.N., (2010), Decision making in public organization, in: Handbook of decision making, P.C. Nutt, (ed.), D. C. Wilson (ed.), Willey-Blackwell,

Simon H. A., (1976), Administrative Behavior. A Study of Decision-Making Processes in Administrative Organization, New York, Macmillan Inc.

Uziębło P., (2009), Demokracja partycypacyjna, Gdańsk, Centrum Badań Społecznych,

Vermeule A., (2007), Mechanisms of democracy: Institutional Design Writ Small, Oxford University Press. 